\title{
18
}

\section{THE INDEPENDENTS}

Jennifer Curtin and Jill Sheppard

The impact of Independents on the fortunes of Liberal-National Coalition governments is often overshadowed by a focus on the minor parties' presence and power in the Senate. This ignores the fact that Independents have been a fixture in the lower house since 1996 and, at various times over this period, either Labor or the Coalition have needed their support to govern. Most recently, this was the case for newly anointed Prime Minister Scott Morrison. Following the election of Independent Kerryn Phelps to Malcolm Turnbull's former seat of Wentworth in October 2018, Morrison's government no longer held a majority. In November that year, on the day after Phelps was sworn in, Liberal MP Julia Banks quit the Liberal Party to sit as an Independent. Although both Phelps and Banks stated their preference to see the government run its full term, these Independents and others proved themselves thorns in the Coalition's side. In November 2018, Cathy McGowan introduced a Bill to establish a national integrity commission with wideranging powers to address perceived corruption and, in December, Phelps introduced the Medevac Bill, the aim of which was to bring asylum seekers detained offshore to Australia for medical treatment. Meanwhile, Banks's presence on the crossbench was a constant reminder of the allegedly toxic culture of the Liberal Party.

These incumbent Independents, and other aspiring Independent candidates, were a highly visible part of the 2019 campaign landscape for a number of reasons. First, alongside the traditional local constituency battles for votes, nationally, a number of Independents banded together 
to champion issues of government integrity, the politics of water and climate change. ${ }^{1}$ Second, there was a small but noisily expressed public disillusionment with the Liberal Party-in part as a response to the nature of Turnbull's dismissal, but also in reaction to allegations of sexism and cronyism and resistance to addressing issues of climate change and coalmining. Thus, in addition to seeing Independents in the Coalition's rural and regional heartlands, the possibility of Independent representation extended to the leafy Liberal suburbs of the major cities. Finally, the 2019 election was to be the year of Independent women. It remains rare to see women elected as Independents in Australia, yet in 2019, the percentage of Independent women candidates increased significantly (up from 12.9 per cent in 2016 to 23.2 per cent). This chapter examines each of these dimensions of the Independents' campaigns and then reviews the results and implications for the future of Independents. For, although history was made when Independent candidate Helen Haines replaced Cathy McGowan as the member for Indi, it is not yet evident that the winning strategies employed in rural and provincial electorates will translate into ongoing success for urban liberal Independents.

\section{The campaigns: A focus on both local and national}

Independents have proved critical to government stability in recent years and their increasing presence can be credited to a combination of factors: a preferential electoral system, single-member districts, the presence of compulsory voting and general disenchantment with the major political parties, particularly among those who live in safe rural and regional seats. Although the election of growing numbers of Independents is not unique to Australia, elsewhere Independents tend to succeed in systems with open party lists and low electoral thresholds (Brancatti 2008).

Nonetheless, international and Australian scholarship points to one common feature associated with successful Independents: the need to be a 'local notable'. This normally requires candidates to be known for

1 Peter Andren was also known for his progressive stance on asylum seekers and parliamentary integrity as the MP for Calare, and Independents have worked together before-for example, in setting up the Independent Candidate's Advisory Network (to encourage others to stand as Independents). However, Andren, Tony Windsor and others chose not to form a 'group' to advance substantive policy issues (Costar and Curtin 2004: 21-23). 
something before standing as an Independent-as local councillors or mayors, sports stars or media personalities (Costar and Curtin 2004). However, the election of McGowan in the Victorian seat of Indi in the 2013 federal election represented something both traditional and new. Her win was traditional in the sense that it reinforced a three-decadeslong, low-level trend whereby a geographical concentration of voters eschewed major party loyalties in favour of local candidates.

This has been particularly evident in rural and regional electorates when the Coalition is in government. Alongside this, were several new dimensions. McGowan's campaign approach, which harnessed communities of support around the electorate, promoted both visibility and voice for the voters of Indi. Her base was far more diverse and inclusive than the discontent tapped 20 years earlier by Pauline Hanson's One Nation. McGowan spoke to young and old from across the political spectrum, many of whom had eschewed tribal party politics and were searching for a different kind of local representative (Curtin and Costar 2015; Curtin 2018).

Another particular feature of the 2019 election was that Independent candidates were better resourced and ostensibly cooperated more closely than in previous years (Grattan and Seaborn 2019). Whereas successful Independents in recent decades have had experience either as party-endorsed legislators or within party institutions, the current cohort of Independent candidates and MPs is markedly different. Instead, they are attracting support from less partisan sources. Two specific but related circumstances appear to have led to this phenomenon: the first is the decline in support for and trust in the major political parties, which has led directly to community-based organisational support for candidates such as Haines; and the second is frustration among many voters over the dearth of progressive climate change policies among those same parties (see, for example, Kassam 2019).

The first form of support, with Voices for Indi as the exemplar, has been covered widely (Curtin and Costar 2015; Grattan and Seaborn 2019; Hendriks 2017). The second is less well understood. A broad coalition of climate change activists-including tech entrepreneur Mike Cannon-Brookes, Australian billionaire's son Simon Holmes à Court and former prime minister Malcolm Turnbull's son, Alex-privately funded environmentally progressive Independents. Some of these funds were channelled through Climate 200 Pty Ltd, an organisation that was registered in April 2019 and which donated $\$ 40,000$ to Julia Banks, 
$\$ 35,000$ to Helen Haines, $\$ 37,000$ to Rob Oakeshott, $\$ 47,500$ to Kerryn Phelps, $\$ 145,000$ to Oliver Yates and $\$ 50,000$ to Independent Senate candidate Anthony Pesec (AEC 2019a). By contrast, Zali Steggall's campaign was funded by a range of wealthy individuals and was claimed to be the most well-resourced of any Independent campaign in Australian history, with a \$1.1 million war chest (Chambers and Caisley 2019; Maley 2019). This kind of organisation among Independent candidatesbased both locally on shared concerns and nationally on specific issue domains-is certainly unprecedented in Australian politics.

Once elected, the 'creative' deliberative approach McGowan practised with the support of Voices for Indi gave her constituents an opportunity to participate in the practice of representation, demystifying federal politics in the process and creating 'respectful, authentic, skilled citizen politicians' (Haines 2019a; Hendriks 2017). Then, in November 2018, Voices for Indi invited around 550 registered campaign volunteers to a January 2019 meeting in the town of Benalla to determine a 'succession process' in advance of McGowan's anticipated retirement prior to the 2019 election (Chan 2018b). Although unprecedented, this approach was deemed necessary for a number of reasons: to 'Keep Indi Independent', to continue to build on McGowan's legacy of 'doing politics differently' and to ensure the campaign infrastructure created to support McGowan remained intact (Koslowski 2019a).

A meeting of around 200 volunteers endorsed Haines as the preferred candidate in mid-January and she began establishing her credentials as a worthy successor to McGowan. She spoke of the importance of valuing inclusion, diversity, listening and 'recognising the power within communities' by building on 'our little movement started in 2013, and what Cathy McGowan championed in office', to 'pass it on to the next community representative who will come after' (Haines 2019a).

Haines's policy positions were informed by conversations with citizens and her own experience in public health. She took an openly pro-choice stance on euthanasia and abortion and supported more funding for health care, education, aged care, the $\mathrm{ABC}$ and sharing regional grants across Australia, rather than privileging Coalition-held seats (Haines 2019b; Somerville and Johnson 2019). Haines opposed the Adani coalmine_-differentiating herself from both the Liberal and the National candidates-and was 
a strong advocate for clean energy and climate change mitigation. In so doing, she invoked the progressive tendencies of some farmers who also recognised the need for new policies on energy and water (Haines 2019b).

Voices for Indi provided dynamic and coherent support for the new candidate, marshalling the well-known 'orange army' of 1,600-1,700 volunteers (spread across Indi's numerous small rural towns and the City of Wodonga). In the end, this amounted to roughly one volunteer for every 20 first-preference votes Haines received. Given the 21-day pre-polling period, this level of 'humanpower' proved critical (Koslowski 2019c). The ground campaign once again had a 'traditional' pre-cartel party feel, with face-to-face conversations, handmade paraphernalia sold at school fetes and music festivals and the requisite colour-coordinated bumper stickers and T-shirts. Haines also used ubiquitous new platforms-in particular, Facebook and Twitter. However, these only supplemented her highly visible presence around the electorate-often accompanied by the still-popular McGowan, thus helping voters to see that a transition from one Independent to another was both simple and natural. This double act was also apparent online, with McGowan's 20,000-plus followers on Twitter regularly reminded of her support for Haines. Their campaign activities were sufficiently successful to attract the attention of Advance Australia (Martin 2019).

The Voices for Indi movement proved contagious in 2019, with a community group called Voices of Warringah (VOW) created to support an alternative candidate to Tony Abbott, who local activists argued had refused to engage with liberals on issues such as climate change and same-sex marriage. These Warringah-based activists formed a committee and interviewed candidates, eventually selecting former Olympian Zali Steggall. 'Kitchen table conversations', pioneered in Indi, were hosted, social media accounts activated and volunteers mobilised.

GetUp! was also prominent in the campaign to oust Abbott, as were at least four other grassroots groups (Davies 2019). Dowse (2019a) recalls there being more than 700 people present at a GetUp! meeting in December 2018, well in advance of Steggall confirming her candidacy. The collective raison d'être of these activists was to unseat Abbott and get climate change on to the Liberals' policy agenda. In a sense, these two issues amounted to a single-issue campaign for Steggall; moderate Liberals were angry at Abbott's determined denial that renewable energy and climate mitigation strategies were necessary let alone desirable (Dowse 2019a). This was 
probably most visible at the Vote Tony Out rally, which attracted an estimated 1,000 protesters and featured former State-level Independent MPs, both of whom endorsed Steggall (Dowse 2019b).

Steggall's campaign also attracted considerable attention from conservative campaigning organisation Advance Australia (see Chapter 21, this volume). Advance Australia released a crude video (later removed) and large billboards linking Steggall to Labor Leader Bill Shorten. These were strategically located on at least one of several main roads through the electorate (and on roaming trucks). Meanwhile, Steggall incurred the wrath of shock jocks on radio station $2 \mathrm{~GB}$ and talkback listeners who argued her supporters were playing the worst kind of dirty politics by linking Abbott and then-convicted Catholic Cardinal George Pell on posters.

Steggall took lessons on campaigning as an Independent from both McGowan and Phelps. Similar to Haines, who was surrounded by orange in Indi, and Phelps by supporters in purple, Warringah was awash with volunteers wearing aqua-coloured T-shirts. It was estimated that Steggall had marshalled over 1,000 supporters on the ground (Dowse 2019a), along with a well-positioned office up the road from Abbott's, a strong social media presence and an experienced team of fundraisers and tacticians.

Steggall also shared with Phelps and Banks the expertise of Damien Hodgkinson, whose experience in community campaigning helped win Phelps the by-election in Wentworth. ${ }^{2}$ Hodgkinson's company, DEM Asia, was reported to be working with eight Independent candidates in setting up campaign infrastructure on the ground, including donor and volunteer databases and advertising, and administering postal vote ballot systems (Middleton 2019). The candidates maintained this was not an Independents' alliance, but rather a means by which to counterbalance the significant resources and knowledge available to the major party candidates (Tingle 2019). It was alleged that the Liberals were sufficiently concerned by Steggall's prospects that the party was spending as much as $\$ 2$ million in the electorate. In Wentworth, voters were also targeted with an onslaught of Liberal-funded mail-outs and robocalls in the final week of the campaign (Witt 2019).

2 Hodgkinson was assisted by Anthony Reed and communications specialist Darrin Barnett, a former media adviser to Julia Gillard (Middleton 2019). 
There were differences, however, between the campaigns of Steggall and Phelps, on the one hand, and Haines on the other. Steggall and Phelps were running against high-profile Liberal candidates in blueribbon urban electorates and their target demographic was disaffected moderate liberals concerned with the Liberal Party's position on climate change. While refugees and some local issues were raised, the campaign messaging concentrated primarily on climate and did not engage in the anti-establishment narrative often associated with non-party candidates. The Sydney Morning Heralds SmartVote tool indicated that Haines, Yates, Steggall and Phelps all held more progressive stances than both the Liberals and Labor on environmental protection and law and order (including the treatment of asylum seekers). However, Steggall and Phelps differed in that they were closer to the Liberals on the economy and were openly opposed to Labor's tax package (Koslowski 2019b).

But 2019 also looked different to previous elections in two other ways. First, a number of Independents expanded their messaging in an effort to force a collective focus on national issues beyond the obvious one of climate change. The focus on national issues was driven in part by a newer breed of Independents-what some have termed the 'sensible centre'-made up of progressive urban Liberals (Denniss 2018). Fifteen Independent candidates ran a video across social media platforms that asked voters to 'rethink the role of Independents', from being political disruptors (thereby distancing themselves from some of the minor parties) to being a 'force for constructive debate' (Tingle 2019).

Prior to this, 12 Independent candidates had jointly called for immediate action on the allegations of misuse of public funds relating to the 2017 purchase of water rights by the federal government from Eastern Australia Irrigation, which was dubbed 'Watergate'. The signatories demanded the government adopt a comprehensive national integrity commission (Crowe 2019). These initiatives followed the parliamentary work of Independent MPs—notably, McGowan and Phelps-who successfully leveraged the balance of power held by the Independents and minor parties to push for change to the medical evacuation regime for asylum seekers on Manus Island and Nauru and to highlight the need for a federal integrity commission to address political corruption. Phelps noted that, during the campaign, the Independents would look to 'cooperate and share resources' and take a stand on issues of national importance, but reassured voters that this would not undermine their autonomy or their freedom to disagree with one another (Tingle 2019). 
The second distinct feature of 2019 was the gender factor. In October 2018, Phelps had issued a call to arms to other women Independents to run for public office (Davies 2018). By March 2019, a number of highprofile women had put themselves forward as Independent candidates, including Louise Stewart in Julie Bishop's former seat of Curtin, Western Australia; Steggall; Alice Thompson in the seat of MacKellar; and Banks in the seat of Flinders. Media outlets around the country were documenting the 'rise of impressive female independent candidates' (Karvelas 2019).

The emergence of strong female independents who were economically conservative but radical on issues such as climate change was seen as a challenge to the Coalition. These women 'invaders' were said to be a consequence of the Coalition being internally split on environmental policy as well as the resistance of both the Liberal Party and the Nationals to selecting, promoting and fostering a culture inclusive of women (Clark 2019; Kenny 2019). Voters were reminded that Steggall, Phelps and Banks were economically conservative, socially progressive women who would normally fit easily within a centre-right party, but who had chosen to run as outsiders (Karvelas 2019). The fallout from the Liberal leadership battle, and its impact on Julie Bishop, remained a constant undercurrent as a result.

Three Sydney-based women lawyers had established 'WomenVote' in advance of the federal election and-like the now 40-year-old strategy of the Women's Electoral Lobby-scored parties on five policies of importance to women. They also used a bright-pink bus to travel to key electorates to canvass women voters' views and ask questions of candidates. They began their campaign in Wentworth and then travelled to Warringah, highlighting that women Independents were standing up for women (Smith 2019). Other women's groups also profiled women Independents. Women's Agenda provided a range of information about the candidates on its website, while 'Connecting Women' organised a panel discussion on gender equality in the electorate of Warringah (Dowse 2019b).

Women were also involved in organisation on the ground; four of the five VOW executive members were women and its secretary, Kathryn Ridge, had run as an Independent at the 2017 NSW by-election after former premier Mike Baird retired (Chan 2018a). Images of Phelps's purple-clad volunteers regularly featured groups of women, and photos of McGowan and Haines campaigning together were an implicit reminder that for too long Independent politics had been dominated by men. Haines said politics and the people of Indi needed intelligent rural women as 
representatives (Priestley 2019). It is difficult to assess the impact of women who helped run the campaigns of the women Independents, but in the case of Indi, Wentworth and Warringah, we do know that all three were explicitly committed to positive rather than negative narratives. The day after the election, a collage displayed in Warringah included the words 'Love Wins' (Dowse 2019c).

\section{The results}

In 2019, fewer Independent candidates stood for the House of Representatives than in 2016 (95 compared with 108), but the number elected increased by one, to three. ${ }^{3}$ The share of the vote Independents received increased to 3.37 per cent (up from 2.8 per cent), although this figure masks a wide variation across States. Independents in South Australia, Western Australia and Queensland attracted less than 1.5 per cent compared with between 3.5 and 5 per cent in New South Wales, Victoria, the Australian Capital Territory and the Northern Territory, and 13 per cent in Tasmania (the last boosted by Andrew Wilkie's success).

Two incumbent Independents ran in 2019: Andrew Wilkie in the renamed and redistributed Tasmanian seat of Clark and Phelps in Wentworth. As indicated in Table 18.1, Wilkie extended his already tight hold on the sparsely populated seat to the south of Hobart, winning sufficient primary votes to be elected outright and increasing his overall margin to 72 per cent. In a sense, Clark is different to the 'usual' regional Independent seat in that the contest was between Wilkie and Labor, rather than a Coalition party candidate.

Phelps, however, was unsuccessful. Second-time Liberal candidate Dave Sharma won Wentworth despite Phelps increasing her primary vote by 3 per cent. Commentators argued that the anger over Turnbull's demise had dissipated, which, in combination with the polls predicting a Labor win and the scare campaign equating voting Independent with support for Labor, undermined Phelps's chances.

3 The drop in the number of Independent candidates may have been a result of the doubling of the deposit required of candidates (see Chapter 3, this volume). Reforms to the Senate electoral system in 2016 also reduced the chances of Independents' success. Nonetheless, 57 Independents nominated for Senate election. Of these, Anthony Pesec was the highest-profile candidate. A climate change and renewable energy activist, he campaigned as a progressive alternative to ACT incumbent Liberal Zed Seselja. Pesec received 12,604 votes-just less than 5 per cent of the vote (but almost 80,000 votes short of being elected). 
Table 18.1 Results for selected Independents, 2016 and 2019

\begin{tabular}{|c|c|c|c|c|c|c|}
\hline \multirow[t]{2}{*}{ Candidate } & \multicolumn{2}{|c|}{ Primary vote } & \multirow{2}{*}{$\begin{array}{l}\text { Percentage } \\
\text { change }\end{array}$} & \multicolumn{2}{|c|}{ TPP } & \multirow{2}{*}{$\begin{array}{l}\text { Percentage } \\
\text { change }\end{array}$} \\
\hline & 2016 & 2019 & & 2016 & 2019 & \\
\hline $\begin{array}{l}\text { Andrew Wilkie } \\
\text { (Clark, formerly } \\
\text { Denison, Tas.) }\end{array}$ & 44.07 & 50.05 & 6.02 & 67.78 & 72.12 & 4.35 \\
\hline $\begin{array}{l}\text { Rob Oakeshott } \\
\text { (Cowper, NSW) }\end{array}$ & 26.29 & 24.49 & -1.80 & 45.44 & 43.21 & -2.23 \\
\hline $\begin{array}{l}\text { Kevin Mack } \\
\text { (Farrar, NSW) }\end{array}$ & & 20.49 & & & 39.06 & \\
\hline $\begin{array}{l}\text { Zali Steggall } \\
\text { (Warringah, NSW) }\end{array}$ & & 43.46 & & & 57.24 & \\
\hline $\begin{array}{l}\text { Kerryn Phelps } \\
\text { (Wentworth, NSW) }\end{array}$ & $\begin{array}{r}29.19 \\
\text { (by-election } \\
2018) \\
\end{array}$ & 32.43 & 2.53 & 51.12 & 48.69 & -2.43 \\
\hline $\begin{array}{l}\text { Alice Thompson } \\
\text { (MacKellar, NSW)) }\end{array}$ & & 12.99 & & & $\begin{array}{r}\text { Placed } \\
\text { 3rd } \\
\end{array}$ & \\
\hline $\begin{array}{l}\text { Julia Banks } \\
\text { (Flinders, Vic.) }\end{array}$ & & 13.79 & & & $\begin{array}{r}\text { Placed } \\
\text { 3rd }\end{array}$ & \\
\hline $\begin{array}{l}\text { Helen Haines } \\
\text { (Indi, Vic.) }\end{array}$ & $\begin{array}{r}34.76 \\
\text { (McGowan) }\end{array}$ & 32.35 & -2.41 & 54.83 & 51.39 & -3.44 \\
\hline $\begin{array}{l}\text { Oliver Yates } \\
\text { (Kooyong, Vic.) }\end{array}$ & & 8.98 & & & $\begin{array}{r}\text { Placed } \\
4 \text { th } \\
\end{array}$ & \\
\hline $\begin{array}{l}\text { Louise Stewart } \\
\text { (Curtin, WA) }\end{array}$ & & 7.75 & & & $\begin{array}{r}\text { Placed } \\
4 \text { th }\end{array}$ & \\
\hline
\end{tabular}

Sources: Compiled by the authors from AEC (2019b); and Curtin (2018).

Wilkie was joined by two new Independents, Haines and Steggall, representing two quite different seats (urban and rural), and both making history: Steggall because the seat of Warringah had always been held by the Liberal Party and Haines because, for the first time federally, one Independent succeeded another. Haines's campaign, like McGowan's in 2016, was challenging in that she was subject to a three-cornered contest, meaning an exchange of preferences between the Liberals and Nationals. It took 25 days to declare the result, with Haines unable to retain McGowan's level of support. The seat of Indi is now one of Australia's most marginal electorates. Steggall, on the other hand, received a healthy 43 per cent primary vote, which translated into a fairly safe margin of 7 per cent. 
Of the remaining high-profile candidates, only Rob Oakeshott came close to the 25 per cent primary vote considered the required minimum to have a chance of winning. The Liberal Party's Sussan Ley held her seat of Farrer on primary votes (50.7 per cent), although Kevin Mack secured 39 per cent of the two-party preferred-a swing against Ley of 7 per cent. Oliver Yates was prolific on social media but failed to reach double figures in Kooyong. He was seeking to unseat Treasurer Josh Frydenberg but the presence of a high-profile Greens candidate, Julian Burnside, complicated the choice for voters concerned about the environment (Burnside won 16 per cent of the primary vote). Julia Banks and Alice Thompson both received more than 12 per cent but failed to draw sufficient votes away from either the Liberal or the Labor candidates.

The cases of Indi, Clark and Warringah reinforce the argument that Independents will often succeed when voters believe political parties have failed to address both local and national interests. These successes are also a reminder that compulsory preferential voting in single-member districts aids the cause of Independents, because disillusioned constituents are compelled to vote and Labor and the Coalition are more likely to direct preferences to Independents than to each other. Thus, when an Independent candidate wins 25 per cent of the primary vote, they have a strong chance of garnering sufficient preferences to reach the required 50 per cent plus one. In most cases, this makes the seat 'marginal' (the contemporary exception is Wilkie).

In the case of rural and regional electorates, this marginal status can result in additional government largesse when the Coalition is in power, reinforcing the power of Independents. However, the example of Phelps suggests the same does not apply to the new urban liberal Independent. For, despite emulating the Indi model, Phelps, Banks, Yates, Steggall and others like them may be perceived as single-issue (climate change) protest candidates, attracting those only momentarily disaffected with their natural party of choice. Whether Steggall can marshal a permanent base of support for the 'sensible centre' remains to be seen. 


\section{References}

Australian Electoral Commission (AEC). 2019a. AEC Transparency Register. Canberra: AEC. transparency.aec.gov.au/.

Australian Electoral Commission (AEC). 2019b. 2019 Federal Election. Canberra: AEC. www.aec.gov.au/Elections/Federal_Elections/2019/index.htm.

Brancatti, Dawn. 2008. 'Winning Alone: The Electoral Fate of Independent Candidates Worldwide'. Journal of Politics 70(3): 648-62. doi.org/10.1017/ S0022381608080675.

Chambers, Geoff and Olivia Caisley. 2019. 'Federal election independent candidates backed by Climate 200 funding vehicle'. The Australian, 5 November. www.theaustralian.com.au/nation/politics/federal-election-independentcandidates-backed-by-climate-200-funding-vehicle/news-story/1a4c635f0bee 627b2a8f97f007491090.

Chan, Gabrielle. 2018a. 'Tony Abbott faces campaign using tactics that defeated Mirabella in Indi'. The Guardian, 6 October. www.theguardian.com/australianews/2018/oct/06/tony-abbott-faces-campaign-using-tactics-that-defeatedmirabella-in-indi.

Chan, Gabrielle. 2018b. 'Cathy McGowan succession process launched by Indi community group'. The Guardian, 30 November. www.theguardian.com/ australia-news/2018/nov/30/cathy-mcgowan-succession-process-launched-byindi-community-group.

Clark, Andrew. 2019. 'Independent invaders could decide election'. Australian Financial Review, 3 May. www.afr.com/news/politics/national/blue-ribbonbattles-independent-invaders-could-decide-election-20190503-p51jp5.

Costar, Brian and Jennifer Curtin. 2004. Rebels with a Cause: Independents in Australian Politics. Sydney: UNSW Press.

Crowe, David. 2019. 'The "price of power": Key independents list their conditions for support in next parliament'. Sydney Morning Herald, 1 May. www.smh. com.au/federal-election-2019/the-price-of-power-key-independents-listtheir-conditions-for-support-in-next-parliament-20190430-p51iqe.html.

Curtin, Jennifer. 2018. 'Independents return and the "almost" hung parliament'. In Double Disillusion: The 2016 Australian Federal Election, edited by Anika Gauja, Peter Chen, Jennifer Curtin and Juliet Pietsch, 359-80. Canberra: ANU Press. doi.org/10.22459/DD.04.2018.16. 
Curtin, Jennifer and Brian Costar. 2015. 'The contest for rural representation: The celebrated contest over Indi and the fate of independents'. In Abbott's Gambit: The 2013 Australian Federal Election, edited by Carol Johnson and John Wanna, with Hsu-Ann Lee, 275-91. Canberra: ANU Press. doi.org/ 10.22459/AG.01.2015.16.

Davies, Anne. 2018. 'Kerryn Phelps and her purple army shake up politics-asusual in Wentworth stunner'. The Guardian, 20 October. www.theguardian. com/australia-news/2018/oct/20/kerryn-phelps-and-her-purple-army-shakeup-politics-as-usual-in-wentworth-stunner.

Davies, Anne. 2019. “'And this is Mosman!": Genteel Warringah rocked by election rancour'. The Guardian, 16 May. www.theguardian.com/australia-news/2019/ may/16/genteel-warringah-rocked-election-rancour-abbott-steggall.

Denniss, Richard. 2018. 'Progressive ideas are becoming the new "sensible centre" of Australian politics'. The Guardian, 28 November. www.theguardian. com/commentisfree/2018/nov/28/progressive-ideas-are-becoming-the-newsensible-centre-of-australian-politics.

Dowse, Sara. 2019a. 'Warringah rises up'. Inside Story, 24 April. insidestory.org.au/ warringah-rises-up/.

Dowse, Sara. 2019b. 'Something's afoot in Warringah'. Inside Story, 7 May. insidestory.org.au/somethings-afoot-in-warringah/.

Dowse, Sara. 2019c. 'Warringah's win'. Inside Story, 20 May. insidestory.org.au/ warringahs-win/.

Grattan, Michelle and Jane Seaborn. 2019. 'The Independents: The cases of Warringah and Wentworth'. In From Turnbull to Morrison: Understanding the Trust Divide, edited by Mark Evans, Michelle Grattan and Brendan McCaffrie, 281-94. Melbourne: Melbourne University Publishing.

Haines, Helen. 2019a. Helen Haines' Bio. Wangaratta, Vic.: Voices for Indi. voices forindi.com/candidate-identification-process/more-about-helen-haines/.

Haines, Helen. 2019b. Helen Haines launches campaign for Indi. 7 April. www.helen haines.org/campaign_launch [page discontinued].

Hendriks, Carolyn M. 2017. 'Citizen-Led Democratic Reform: Innovations in Indi'. Australian Journal of Political Science 52(4): 481-99. doi.org/10.1080/ 10361146.2017.1374345. 
Karvelas, Patricia. 2019. 'Women are pushing to the front of the queue in 2019 Australian politics'. ABC News, 30 January. www.abc.net.au/news/201901-30/zali-steggall-tony-abbott-kelly-odwyer-australian-politics-women/ 10761552.

Kassam, Natasha. 2019. Lowy Institute Poll 2019. Sydney: Lowy Institute. www.lowyinstitute.org/publications/lowy-institute-poll-2019.

Kenny, Mark. 2019. 'Liberals lose yet another high-profile woman, yet still no action on gender'. The Conversation, 21 January. theconversation.com/liberalslose-yet-another-high-profile-woman-yet-still-no-action-on-gender-110158.

Koslowski, Max. 2019a. 'Cathy McGowan, trailblazing independent MP, to quit politics at the election'. Sydney Morning Herald, 14 January. www.smh.com.au/ politics/federal/cathy-mcgowan-trailblazing-independent-mp-to-quit-politicsat-the-election-20190114-p50r6v.html.

Koslowski, Max. 2019b. 'Are independents really from the "sensible centre"? Smartvote Australia asked 50 of them'. Sydney Morning Herald, 7 May. www. smh.com.au/federal-election-2019/are-independents-really-from-the-sensiblecentre-smartvote-australia-asked-50-of-them-20190507-p51kr2.html.

Koslowski, Max. 2019c. "AA school fete on steroids": How the first ever independent handover triumphed'. Sydney Morning Herald, 20 May. www. smh.com.au/federal-election-2019/a-school-fete-on-steroids-how-the-firstever-independent-handover-triumphed-20190520-p51p6y.html.

Maley, Jacqueline. 2019. 'Steggall's campaign was powered by a $\$ 1.1$ million donations war chest'. Sydney Morning Herald, 4 November. www.smh.com.au/ politics/federal/steggall-s-campaign-was-powered-by-a-1-1-million-donationswar-chest-20191101-p536nh.html.

Martin, Lisa. 2019. 'Independent's day? The orange army and its battle for Indi'. The Guardian, 23 April. www.theguardian.com/australia-news/2019/apr/23/ independents-day-the-orange-army-and-its-battle-for-indi.

Middleton, Karen. 2019. 'The campaigner behind Phelps, Banks and Steggall'. The Saturday Paper, No. 242, 2-8 March. www.thesaturdaypaper.com.au/ news/politics/2019/03/02/the-campaigner-behind-phelps-banks-and-steggall/ 15514452007567.

Priestley, Angela. 2019. “"I have strength in my hands”: Midwife Helen Haines to take on major parties, replacing Cathy McGowan'. Women's Agenda, 13 January. womensagenda.com.au/latest/i-have-strength-in-my-hands-midwifehelen-haines-to-taking-on-major-parties-replacing-cathy-mcgowan/. 
Smith, Alexandra. 2019. 'Wentworth candidates board the big pink bus'. Sydney Morning Herald, 1 May. www.smh.com.au/federal-election-2019/wentworthcandidates-board-the-big-pink-bus-20190501-p51j2q.html.

Somerville, Erin and Sian Johnson. 2019. 'Independent MP accuses federal government of politicising regional grants'. $A B C$ News, 6 March. www.abc. net.au/news/2019-03-06/mcgowan-lodges-official-complaint-over-grantannouncements/10876004.

Tingle, Laura. 2019. 'Federal election 2019: Independents band together to take on political parties'. ABC News, 7 May. www.abc.net.au/news/2019-05-07/ independents-advert-takes-on-political-parties-laura-tingle/11084804.

Witt, Merrill. 2019. 'Independents' success offers silver lining'. CityHub, [Sydney], 22 May. www.altmedia.net.au/independents-success-offers-silverlining/139639. 
This text is taken from Morrison's Miracle: The 2019 Australian Federal Election, edited by Anika Gauja, Marian Sawer and Marian Simms, published 2020 by ANU Press, The Australian National University, Canberra, Australia.

doi.org/10.22459/MM.2020.18 